\title{
Tank Rehabilitation Index for a Tank Cluster
}

\author{
Kalaiarasi M. S $^{1^{*}}$, Carolin Arul ${ }^{1}$
}

${ }^{1}$ Centre for Water Resources, Department of Civil Engineering, Anna University, Guindy, Chennai, Tamil Nadu 600025, India

DOI: $10.36347 /$ sjavs.2022.v09i01.001

| Received: 13.12.2021 | Accepted: 18.01.2022 | Published: 20.01.2022

*Corresponding author: Kalaiarasi M. S

Centre for Water Resources, Department of Civil Engineering, Anna University, Guindy, Chennai, Tamil Nadu 600025, India

\section{Abstract}

Restoration and rehabilitation of irrigation tanks is gaining much attention due to the increased temporal variation in the rainfall. This study was carried out in the first four tanks (i.e. Arungunam, Devadur, Mariputhur and Kavadur tanks) of the Madurantakam tank cluster, which lies in the Kiliyar sub basin, Palar basin, Tamil Nadu, India. The study was aimed at assessing the performance of the tanks and deriving a Tank Rehabilitation Index (TRI) for prioritizing the tanks based on 24 indicators reflecting the physical, hydrological and socio technical aspects. The physical performance of the tanks was measured in terms of their storage capacity. Capacity estimation was carried out using Bathymetry survey and Google earth. The results showed that the Kavadur tank performed well with $89.29 \%$ storage capacity when compared with the Arungunam, Devadur and Mariputhur tanks having 75\%, 57.42\% and $42.11 \%$ as their storage capacities respectively. A score-based method was adopted in finding out the TRI. It was found that the Kavadur tank tops the priority for rehabilitation with a score of 14.50 followed by the Arungunam and Devadur tank with a score of 14.25. The Mariputhur tank scored the least (13.75). Much variation in the TRI developed could be obtained, if the tanks were selected randomly over different reaches of the cluster.

Keywords: Tank prioritization, Tank capacity, Performance indicators, Tank rehabilitation index, Bathymetry.

Copyright (C) 2022 The Author(s): This is an open-access article distributed under the terms of the Creative Commons Attribution 4.0 International License (CC BY-NC 4.0) which permits unrestricted use, distribution, and reproduction in any medium for non-commercial use provided the original author and source are credited.

\section{INTRODUCTION}

Tanks are the traditional water harvesting structures, which supplements the monsoon rains to sustain agricultural production and to fulfill the various ecological demands. Around 39,000 tanks are situated in Tamil Nadu (Palanisamy and Ruth, 2001). The climate change has led to frequent flood and drought conditions, which has resulted in water scarcity, crop failure and inundation of tank command area during flash floods, affecting the livelihood of the farmers. It is essential to make productive use of the available water resources in a watershed to face the climatic extremes. Tanks serve as the lifeline of people; hence emphasis must be given to the maintenance and improvement of the irrigation structures.

For making productive use of the available water in a watershed, assessment and rehabilitation of the existing irrigation systems must be carried out (Nagarajan, 2013). The high resolution satellite data could be used for identifying the current status of the tank components, the land use/land cover changes in the tank catchment and its command area, cropping intensity in various seasons, cropping pattern, delineation of the watershed boundary and identifying the current drainage pattern (Hakeem and Raju, 2008; Krishnaveni et. al., 2011). A tank could be taken up for rehabilitation based upon three major factors such as cropping intensity, ratio of catchment area to waterspread area and ratio of command area to waterspread area (Sakthivadivel et. al., 1996). The condition of tank components, water sharing arrangements, water availability in the tank and water distribution contributes for the participation of farmers in tank related activities (Jana and Lise, 2013). The multiple uses of the tank should also be considered for evaluating the tank potential with a view of providing maximum benefits from the tank (Palanisamy and Ruth, 2001). Thus a holistic socio-technical approach is needed for rehabilitating an irrigation system.

\section{STUDY AREA}

Four tanks (out of 30 tanks) in the upper reach of the Madurantakam tank cluster (with Madurantakam as the head tank) were chosen for the study. The Madurantakam tank cluster lies in the Kiliyar sub basin of the Palar basin, Tamil Nadu. The main sources of supply to the Madurantakam tank are the Kiliyar River (a tributary of river Palar) and Nelvoy Maduvu, a supply channel which connects the Madurantakam and 
the Uthiramerur tanks. A supply channel from the left flank feeds the Karunguzhi tank, the surplus of which drains back into the Kiliyar river. A supply channel from the right flank feeds 30 tanks in a chain. Depending on the ratio of catchment area to waterspread area, the first four tanks fed by the high level channel scheme (Arungunam tank, Mariputhur tank, Devadur tank and Kavadur tank) were taken for the study. The waterspread area was delineated from the toposheets 57P14 and 57P15 (1:50,000 scale), using ArcGIS and Google Earth captured during the month of
November and December when the tank is at Full Tank Level (F.T.L).

\section{OBJECTIVES AND METHODOLOGY}

This study aimed to assess the performance of the tanks in a cluster and to derive the tank rehabilitation index based on the hydrological and physical status of tanks adopting a socio technical approach. To assess the performance of the tanks, a methodology was developed as shown in Figure 1. The sample size for the questionnaire survey is sixty.

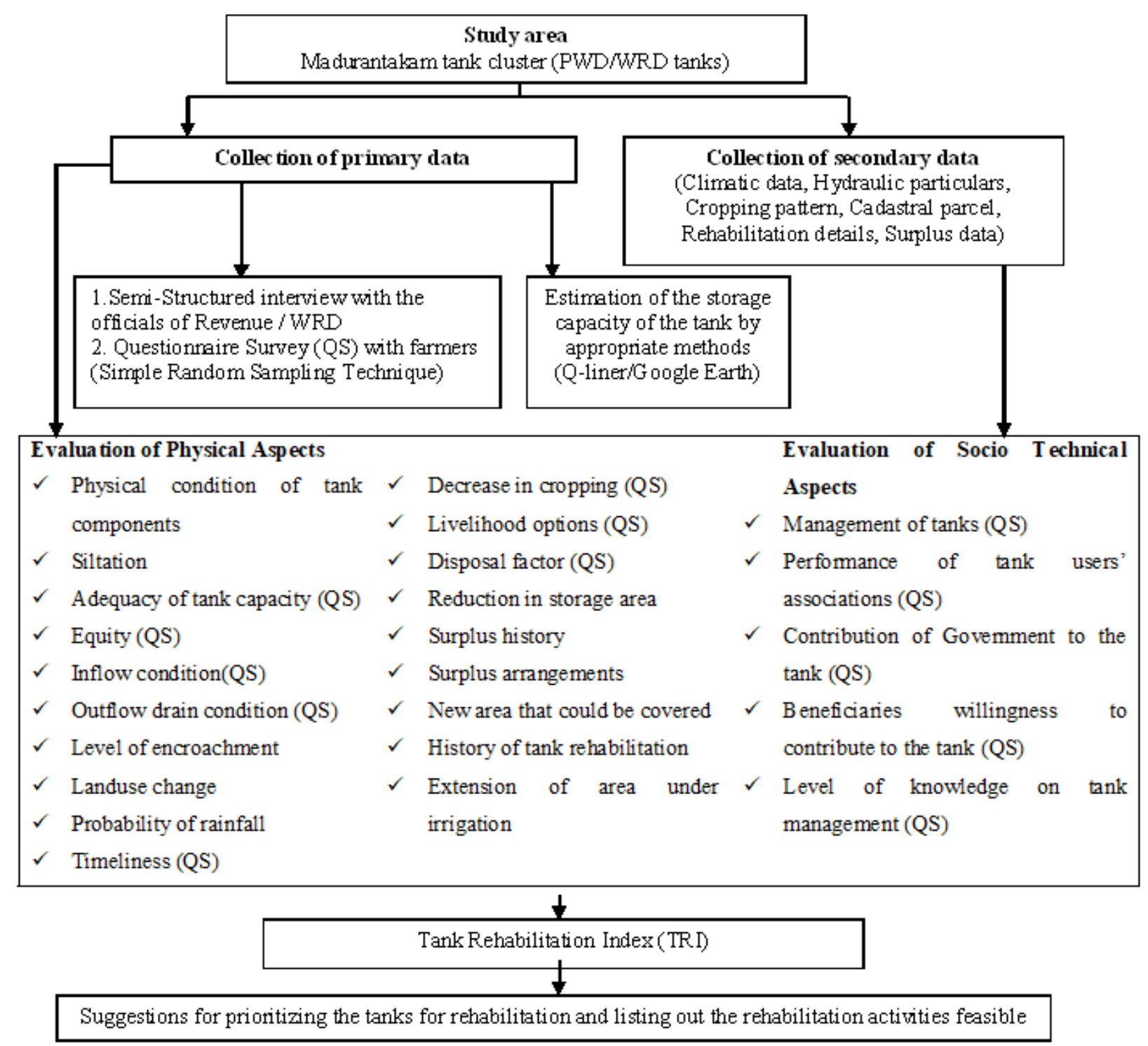

Figure 1: Methodology for Prioritization of Tanks in a Cluster

The Cartosat DEM with $2.5 \mathrm{~m}$ resolution was used for delineating the watershed by using ArcGIS. The storage capacity of the tanks was taken as an indicator for measuring its performance and was estimated by two methods as shown in Figure 2. 


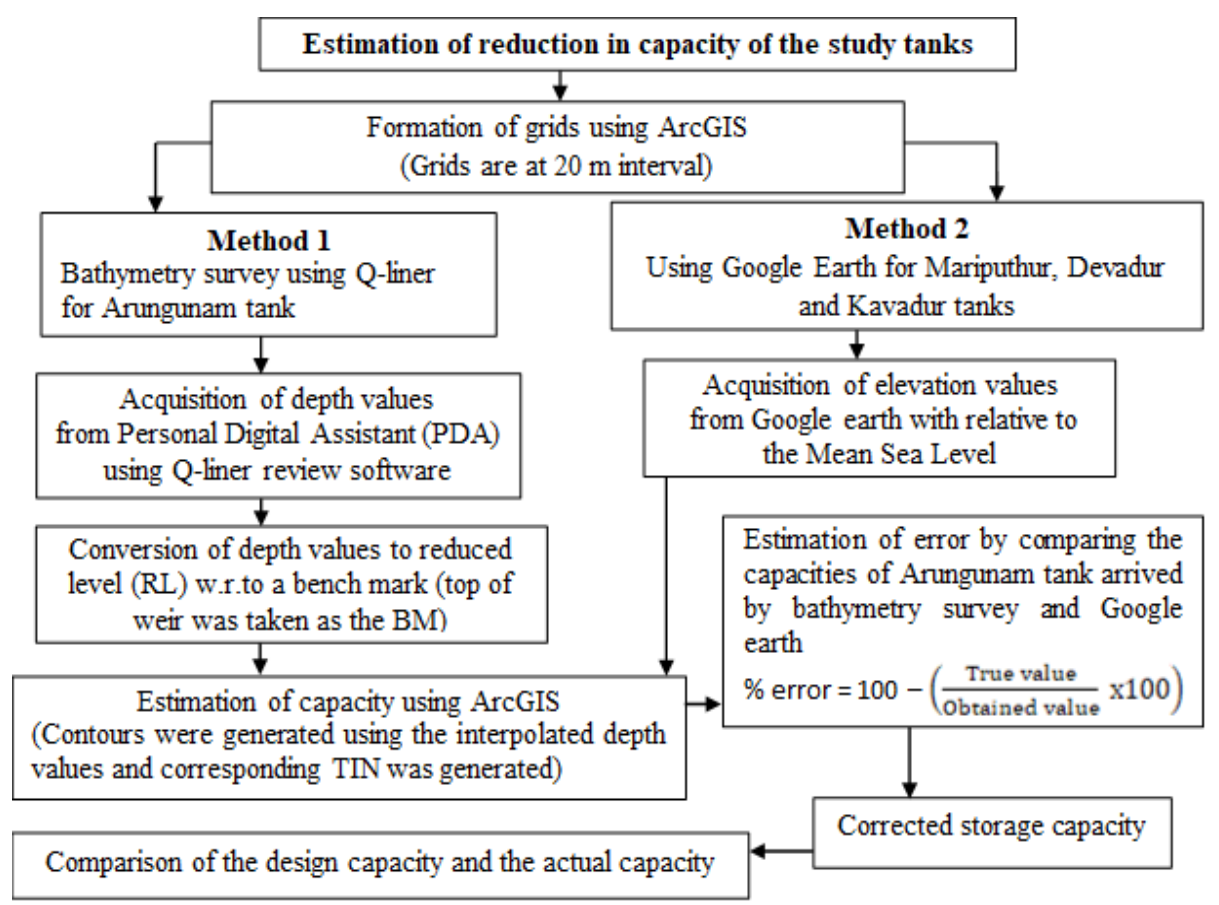

Figure 2: Capacity Estimation of the Tanks

The waterspread area of the tank delineated from Google Earth was used in the formation of grids at $20 \mathrm{~m}$ x $20 \mathrm{~m}$ interval using ArcGIS. Bathymetry survey was carried out in the Arungunam tank using Q-liner (Figure 3) and demarcation of the waterspread boundary was carried out using a hand-held GPS (Figure 4). The readings were taken at every 90 seconds interval along a line. Then the next line was taken up which was set out with an offset of $20 \mathrm{~m}$ from the first line. Q-liner could be used to measure depths ranging between $0.35 \mathrm{~m}$ to $10 \mathrm{~m}$. The points where the depth was less than $0.35 \mathrm{~m}$ were measured by using a scale arrangement Depths were measured at 148 points in the waterspread area during the survey (99 points taken using the Q-liner and 49 points using a scale arrangement. The data stored in the Personal Digital Assistant (PDA) were retrieved using the Q-liner review software. The depth values obtained from the PDA were converted to reduced levels (RL) with respect to the top of weir.

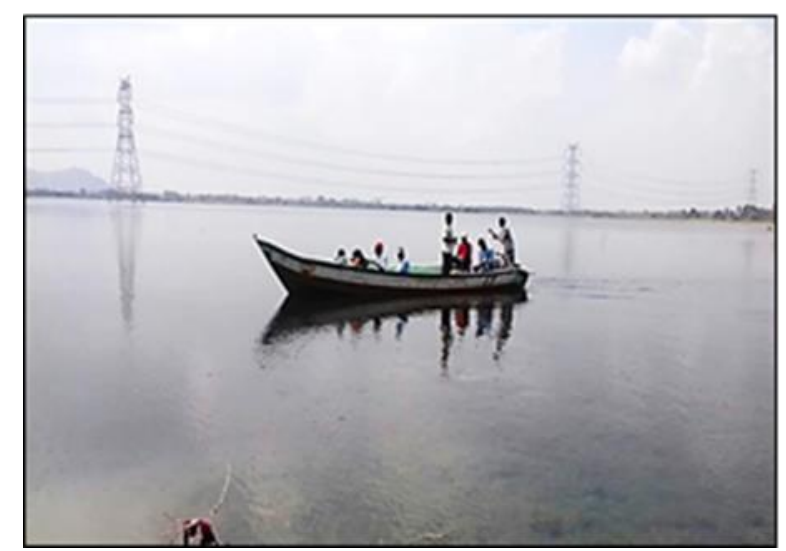

Figure 3: Bathymetry survey using Q-liner

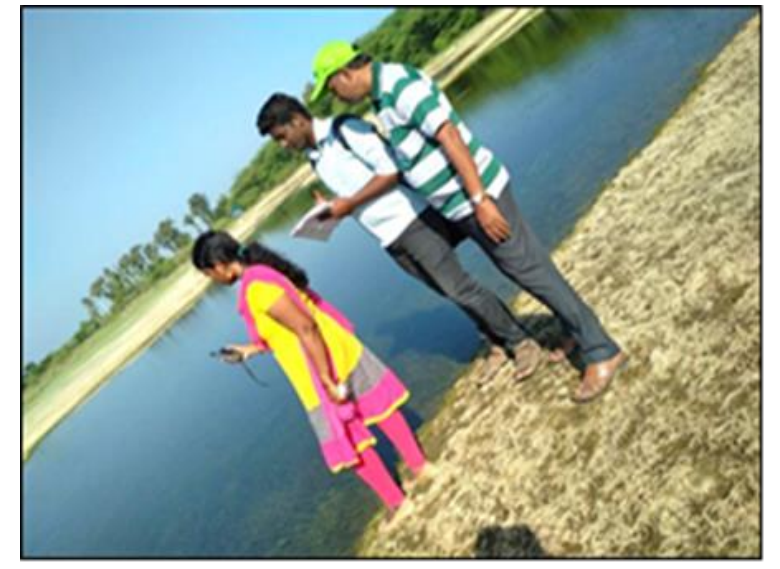

Figure 4: Demarcation of the waterspread boundary using a hand-held GPS

The points surveyed were mapped using ArcGIS and the corresponding depth values were interpolated using Kriging method for the entire waterspread. Contours were generated from the interpolated values at an interval of $0.05 \mathrm{~m}$ followed by Triangulated Irregular Networks (TIN) from which the capacity of the tank was estimated using the surface volume tool.

The steps followed in capacity estimation using Google Earth were similar to that of the steps followed in capacity estimation by the Bathymetry survey, except that the elevation points were obtained from the Google Earth. The difference in capacities of the Arungunam tank was obtained from both the methods, which gave a percentage of error in the capacity estimation using Google Earth as 30\%. The approximate capacities of Devadur, Kavadur and 
Mariputhur tanks were arrived based on this percentage of error.

\subsection{Physical aspects}

Rehabilitation will be effective only when the physical components of the tank like the bund, sluices, surplus weir, bed, inflow and outflow channels are in good condition. Rehabilitating a highly degraded tank will be time consuming and requires more financial assistance. The functioning of the tank components was evaluated based on the physical observations, semistructured interview conducted with the Officials and questionnaire survey administered with the farmers.

The tank with a high level of siltation must be given priority, as it reduces the storage levels, which may lead to decline in the command area and may gradually go unused. The adequacy of the tank capacity indicates the inability of the tank to meet out the irrigation demands. If the tank fails to meet the demand, then it needs more attention. In such cases, increasing the storage depth in potential areas could be attempted. Equity in water distribution indicates that there is no water sharing problem and thus the water from the tank could be used efficiently by the farmers and such tanks could be preferred for rehabilitation.

Encroachment in a tank system could be seen more commonly in the bed, feeder channels and bund, which could be witnessed in terms of households and as agricultural fields. The level of encroachment was mapped out using the Google Earth imagery by overlaying the shape file obtained from the toposheet, Survey of India.

The change in landuse was obtained by demarcating the command area of the tanks in the Google Earth using the cadastral map obtained from the Water Resources Department (WRD)/Public Works Department (PWD), Madurantakam. The temporal images in the Google Earth were used to find out the landuse changes in the tank command area. This study aimed at mapping the fallow lands as there is no urban sprawl in the study tanks. History of rehabilitation obtained from WRD/PWD, Madurantakam indicates the way of prioritizing the tanks based on the past rehabilitation activities such that the tank which has not undergone rehabilitation over a long period of time could be given more preference.

Rehabilitation would be effective only if the tank receives sufficient amount of rainfall. Hence, the frequency analysis was done using Weibull's method using 20 years rainfall data $(n=20)$. From the analysis, the $75 \%$ dependable rainfall was found to be $789.1 \mathrm{~mm}$ with a corresponding return period of one year three months. This was around $65 \%$ of the normal annual rainfall $(1,214 \mathrm{~mm})$ of the district.
Decrease in the cropping season could be taken as an indicator of the water unavailability in the tank as a result of reduction in the storage capacity. Rehabilitating such tanks proves to regain its original potential. The multiple uses of the tank apart from irrigation such as the ecological services and livelihood activities must be given more importance while taking up the tank for rehabilitation.

Disposal factor takes into account the ease in disposing the silt that is taken up from the tank bed which calls for the involvement of the local people. Disposal of huge quantum of silt is a major hindrance faced in tank bed desilting apart from the financial constraints.

The surplus history indicates whether there is huge potential for increasing the storage capacity of the tank in order to make productive use of the surplus water. The study tanks had surplused seven times in the last 10 years. Also, a proper surplus arrangement is required in order to make sure that the excess water is disposed off safely without causing any damage to the structure. The surplus arrangement in the Arungunam tank was found to be inadequate.

Potential for extension of the ayacut could be considered while taking up a tank for rehabilitation as it aids in improving the overall productivity, which was evaluated based on the presence of more fallow lands within the ayacut and which could be brought under irrigation.

\subsection{Socio-technical aspects}

A well-managed tank can be evaluated based on the reliability, timeliness and equity in water supply, performance of the tank, accountability of the staff, flexibility in management, operation and maintenance activities in the tank and a good interaction between the Officials and the Water Users' Associations.

The interaction of the farmers with the Officials and coordination among the farmers in the command area are very essential for better management of the available water resources. If there is good contribution from the government side for operation and maintenance activities of the tank, the sustainability of tank rehabilitation could be ensured.

Higher involvement of the beneficiaries in tank management enhances proper functioning of the tank. The level of knowledge on tank management is of great importance, if the farmers are ready to take up the tank for O\&M activities. Proper training to both the Officials and beneficiaries are required for an integrated functioning of the system.

\section{RESULTS AND DISCUSSION}

The prime purpose of the tank is to store the runoff from the catchment and rainfall in its 
Kalaiarasi M. S \& Carolin Arul., Sch J Agric Vet Sci, Jan, 2022; 9(1): 1-8

waterspread area, which can be put to beneficial usage. Hence the performances of the tanks were evaluated based on their present storage capacity as it represents the functioning of the system as a whole. Table 1 represents the storage capacity of the tanks and percentage reduction from the design capacity.

Table 1: Performance of tanks in terms of their storage capacity

\begin{tabular}{|l|l|l|l|l|}
\hline Sl. No & Name of the tank & Design Capacity (MCM) & Present Capacity (MCM) & Reduction in capacity (\%) \\
\hline 1 & Arungunam & 1.72 & 1.29 & 25 \\
\hline 2 & Mariputhur & 0.38 & 0.16 & 57.89 \\
\hline 3 & Devadur & 0.40 & 0.23 & 42.48 \\
\hline 4 & Kavadur & 0.28 & 0.25 & 10.71 \\
\hline
\end{tabular}

The reduction in storage capacity was high in Mariputhur and Devadur tank, whereas it was moderate in the Arungunam tank and comparably low in the Kavadur tank. The reduction in storage capacities could be accounted for the siltation in the tanks. The reduction in waterspread area was obtained with the aid of Google Earth and it was found to be moderate in the study tanks with the Kavadur tank showing a maximum of $16.67 \%$ reduction in storage area followed by the Devadur tank with $10.46 \%$ reduction in storage area, the Mariputhur tank with $9.76 \%$ reduction in storage area and the Arungunam tank with $9.09 \%$ reduction in storage area.

Encroachments in the tank waterspread area were observed to be $6.43 \%, 2.10 \%, 2.66 \%$ and $0.13 \%$ in the Arungunam, the Mariputhur, the Devadur and the Kavadur tanks respectively. Water distribution system was found to be good and equity in water supply is maintained in all the study tanks. The cropping season has reduced from 2 to 1 over the past 20 years as the tank water is adequate for meeting out the irrigation demands of only one crop season. The farmers with wells go for second crop. Apart from irrigation, the study tanks aid in supply of drinking water for humans, animals and birds, and help to recharge groundwater. Fish rearing was observed only in the Arungunam tank.
The landuse change was mapped using Google Earth and it was found to be minimal as there was no urbanization in the study tanks.

The farmers are ready to contribute for the management of tanks in the form of labor and willing to take up the silt for their use depending on its quality, if disposal of the silt could be a problem while desilting the tank. All the study tanks scored least in the sociotechnical aspects. The management followed a top down approach and there was little interaction between the farmers and the Officials. The performance of the tank users' associations was found low, as they do not have a well-defined function. Most of the farmers do not have much knowledge about the Tank Users' Associations' and they do not have adequate training for the management of the tanks even though they are willing to take part.

\subsection{Tank Rehabilitation Index (TRI)}

The Tank Rehabilitation Index (TRI) was derived by adopting a score-based method. Table 2 represents the classification of scores based on their relevance to rehabilitation aspects. The tank which has obtained the maximum score would be taken up for rehabilitation on priority basis.

Table 2: Score-based classification on rehabilitation aspects

\begin{tabular}{|l|l|l|l|}
\hline Sl. No & Parameter & Class & Score \\
\hline 1 & Physical condition of the tank components & Less than $80 \%$ & 1 \\
& (Based on their performance in an order of good to poor ) & $80 \%-50 \%$ & 0.75 \\
& & $50 \%-20 \%$ & 0.5 \\
& & Greater than 20\% & 0.25 \\
\hline 2 & Adequacy of tank capacity & Less than 50\% & 1 \\
& (Based on its ability to meet the irrigation demands in an order of low & $50 \%-70 \%$ & 0.75 \\
& to high) & $70 \%-90 \%$ & 0.5 \\
& & Greater than $90 \%$ & 0.25 \\
\hline 3 & Drainage conditions & Excellent & 1 \\
& & Good & 0.75 \\
& & Medium & 0.5 \\
& Inflow conditions & Bad & 0.25 \\
\hline 5 & & Excellent & 1 \\
& & Good & 0.75 \\
& Siltation & Medium & 0.5 \\
& (high to low $)$ & Bad & 0.25 \\
\hline & & Greater than $60 \%$ & 1 \\
\end{tabular}


Kalaiarasi M. S \& Carolin Arul., Sch J Agric Vet Sci, Jan, 2022; 9(1): 1-8

\begin{tabular}{|c|c|c|c|}
\hline Sl. No & Parameter & Class & Score \\
\hline 6 & Surplus arrangements & $\begin{array}{l}\text { Excellent } \\
\text { Good } \\
\text { Medium } \\
\text { Bad }\end{array}$ & $\begin{array}{l}1 \\
0.75 \\
0.5 \\
0.25\end{array}$ \\
\hline 7 & $\begin{array}{l}\text { Encroachments } \\
\text { (high to low) }\end{array}$ & $\begin{array}{l}\text { Greater than } 50 \% \\
50 \%-30 \% \\
30 \%-10 \% \\
\text { Less than } 10 \%\end{array}$ & $\begin{array}{l}1 \\
0.75 \\
0.5 \\
0.25\end{array}$ \\
\hline 8 & $\begin{array}{l}\text { Timeliness } \\
\text { (Based on the release of water high to low) }\end{array}$ & $\begin{array}{l}\text { Excellent } \\
\text { Good } \\
\text { Medium } \\
\text { Bad }\end{array}$ & $\begin{array}{l}1 \\
0.75 \\
0.5 \\
0.25\end{array}$ \\
\hline 9 & $\begin{array}{l}\text { Extension of area under irrigation } \\
\text { (New areas that could be possibly covered in an order of high to } \\
\text { low) }\end{array}$ & $\begin{array}{l}\text { Greater than } 50 \% \\
50-30 \% \\
30-10 \% \\
\text { Less than } 10 \%\end{array}$ & $\begin{array}{l}1 \\
0.75 \\
0.5 \\
0.25\end{array}$ \\
\hline 10 & $\begin{array}{l}\text { Equity } \\
\text { (Based on the water distribution from head to tail end in an order } \\
\text { of high to low) }\end{array}$ & $\begin{array}{l}\text { Greater than } 90 \% \\
90 \%-70 \% \\
70 \%-50 \% \\
\text { Less than } 50 \%\end{array}$ & $\begin{array}{l}1 \\
0.75 \\
0.5 \\
0.25 \\
\end{array}$ \\
\hline 11 & $\begin{array}{l}\text { History of rehabilitation } \\
\text { (Based on year the when the tank had undergone rehabilitation } \\
\text { lately in the past } 20 \text { years in an order of low to high) }\end{array}$ & $\begin{array}{l}\text { Greater than } 15 \text { years } \\
15 \text { - } 10 \text { years } \\
10 \text { - } 5 \text { years } \\
\text { Less than } 5 \text { years }\end{array}$ & $\begin{array}{l}1 \\
0.75 \\
0.5 \\
0.25\end{array}$ \\
\hline 12 & $\begin{array}{l}\text { Probability of rainfall } \\
\text { (Based on the return period of } 75 \% \text { dependable rainfall calculated } \\
\text { using Weibull's method) }\end{array}$ & $\begin{array}{l}\text { Less than } 1 \text { year } \\
1-3 \text { years } \\
3 \text { - } 5 \text { years } \\
\text { Greater than } 5 \text { years }\end{array}$ & $\begin{array}{l}1 \\
0.75 \\
0.5 \\
0.25\end{array}$ \\
\hline 13 & $\begin{array}{l}\text { Surplus history } \\
\text { (Based on the number of surplusing years of the tanks in the past } \\
20 \text { years in an order of high to low) }\end{array}$ & $\begin{array}{l}\text { Greater than } 15 \text { years } \\
15 \text { - } 10 \text { years } \\
10 \text { - } 5 \text { years } \\
\text { Less than } 5 \text { years }\end{array}$ & $\begin{array}{l}1 \\
0.75 \\
0.5 \\
0.25 \\
\end{array}$ \\
\hline 14 & Reduction in storage area & $\begin{array}{l}\text { Greater than } 50 \% \\
50-30 \% \\
30-10 \% \\
\text { Less than } 10 \%\end{array}$ & $\begin{array}{l}1 \\
0.75 \\
0.5 \\
0.25\end{array}$ \\
\hline 15 & $\begin{array}{l}\text { Landuse change } \\
\text { (Based on the change in the landuse in the command area in an } \\
\text { order of high to low) }\end{array}$ & $\begin{array}{l}\text { Greater than } 50 \% \\
50-30 \% \\
30-10 \% \\
\text { Less than } 10 \%\end{array}$ & $\begin{array}{l}1 \\
0.75 \\
0.5 \\
0.25\end{array}$ \\
\hline 16 & $\begin{array}{l}\text { Disposal factor } \\
\text { (Depending on the ease of disposal of the silt in an order of high to } \\
\text { low) }\end{array}$ & $\begin{array}{l}\text { Greater than } 90 \% \\
90 \%-70 \% \\
70 \%-50 \% \\
\text { Less than } 50 \%\end{array}$ & $\begin{array}{l}1 \\
0.75 \\
0.5 \\
0.25 \\
\end{array}$ \\
\hline 17 & Decrease in cropping season & $\begin{array}{l}\text { Greater than } 75 \% \\
75 \%-50 \% \\
1850 \%-25 \% \\
\text { Less than } 25 \%\end{array}$ & $\begin{array}{l}1 \\
0.75 \\
0.5 \\
0.25 \\
\end{array}$ \\
\hline 18 & $\begin{array}{l}\text { Livelihood options } \\
\text { (Considering the multiple uses of the tank) }\end{array}$ & $\begin{array}{l}\text { Highly dependent } \\
\text { Dependent } \\
\text { Medium } \\
\text { Less dependent }\end{array}$ & $\begin{array}{l}1 \\
0.75 \\
0.5 \\
0.25\end{array}$ \\
\hline 19 & Management of tanks & $\begin{array}{l}\text { Excellent } \\
\text { Good } \\
\text { Medium } \\
\text { Bad }\end{array}$ & $\begin{array}{l}1 \\
0.75 \\
0.5 \\
0.25\end{array}$ \\
\hline
\end{tabular}


Kalaiarasi M. S \& Carolin Arul., Sch J Agric Vet Sci, Jan, 2022; 9(1): 1-8

\begin{tabular}{|c|c|c|c|}
\hline SI. No & Parameter & Class & Score \\
\hline 20 & Performance of tank users' associations & $\begin{array}{l}\text { Excellent } \\
\text { Good } \\
\text { Medium } \\
\text { Bad }\end{array}$ & $\begin{array}{l}1 \\
0.75 \\
0.5 \\
0.25\end{array}$ \\
\hline 21 & Government contribution to the tank & $\begin{array}{l}\text { Excellent } \\
\text { Good } \\
\text { Medium } \\
\text { Bad }\end{array}$ & $\begin{array}{l}1 \\
0.75 \\
0.5 \\
0.25 \\
\end{array}$ \\
\hline 22 & $\begin{array}{l}\text { Beneficiaries willingness to contribute to the tank } \\
\text { (in terms of money or labour) }\end{array}$ & $\begin{array}{l}\text { Excellent } \\
\text { Good } \\
\text { Medium } \\
\text { Bad }\end{array}$ & $\begin{array}{l}1 \\
0.75 \\
0.5 \\
0.25 \\
\end{array}$ \\
\hline 23 & Level of awareness and knowledge on tank management & $\begin{array}{l}\text { Excellent } \\
\text { Good } \\
\text { Medium } \\
\text { Bad }\end{array}$ & $\begin{array}{l}1 \\
0.75 \\
0.5 \\
0.25 \\
\end{array}$ \\
\hline 24 & Level of training on tank management & $\begin{array}{l}\text { Excellent } \\
\text { Good } \\
\text { Medium } \\
\text { Bad } \\
\end{array}$ & $\begin{array}{l}1 \\
0.75 \\
0.5 \\
0.25 \\
\end{array}$ \\
\hline
\end{tabular}

The TRI obtained for the study tanks were tabulated in the Table 3. The score-based approach proves to be beneficial in evaluating the rehabilitation aspects of the tanks as well as helps in identifying the rehabilitation activities that should be carried out in the selected tanks.

Table 3: Determination of Tank Rehabilitation Index

\begin{tabular}{|l|l|l|l|l|l|}
\hline \multirow{2}{*}{$\begin{array}{l}\text { Sl. } \\
\text { No. }\end{array}$} & Parameter & Score & \multicolumn{2}{l|}{} \\
\cline { 3 - 6 } & & $\begin{array}{l}\text { Arungunam } \\
\text { tank }\end{array}$ & $\begin{array}{l}\text { Mariputhur } \\
\text { tank }\end{array}$ & $\begin{array}{l}\text { Devadur } \\
\text { tank }\end{array}$ & $\begin{array}{l}\text { Kavadur } \\
\text { tank }\end{array}$ \\
\hline 1 & Physical condition of the tank components & 0.75 & 0.75 & 0.75 & 1 \\
\hline 2 & Adequacy of tank capacity & 0.25 & 0.25 & 0.25 & 0.25 \\
\hline 3 & Drainage conditions & 0.75 & 0.75 & 0.75 & 0.75 \\
\hline 4 & Inflow conditions & 1 & 0.75 & 0.75 & 0.75 \\
\hline 5 & Siltation & 0.5 & 0.75 & 0.75 & 0.25 \\
\hline 6 & Surplus arrangements & 0.5 & 1 & 1 & 1 \\
\hline 7 & Encroachments & 0.25 & 0.25 & 0.25 & 0.25 \\
\hline 8 & New area to be included & 0.25 & 0.25 & 0.25 & 0.25 \\
\hline 9 & Equity & 1 & 1 & 1 & 1 \\
\hline 10 & Timeliness & 1 & 1 & 1 & 1 \\
\hline 11 & History of rehabilitation & 0.25 & 0.25 & 0.25 & 1 \\
\hline 12 & Probability of rainfall & 0.75 & 0.75 & 0.75 & 0.75 \\
\hline 13 & Surplus history & 1 & 1 & 1 & 1 \\
\hline 14 & Reduction in storage area & 0.25 & 0.25 & 0.5 & 0.5 \\
\hline 15 & Landuse change & 0.25 & 0.25 & 0.25 & 0.25 \\
\hline 16 & Disposal factor & 1 & 0.75 & 0.75 & 0.75 \\
\hline 17 & Decrease in cropping season & 0.75 & 0.75 & 0.75 & 0.75 \\
\hline 18 & Livelihood options & 1 & 0.75 & 0.75 & 0.75 \\
\hline 19 & Management of tanks & 0.25 & 0.25 & 0.25 & 0.25 \\
\hline 20 & Performance of tank users' associations & 0.25 & 0.25 & 0.25 & 0.25 \\
\hline 21 & Government contribution to the tank & 0.75 & 0.5 & 0.75 & 0.5 \\
\hline 22 & Beneficiaries willingness to contribute to the tank & 1 & 0.75 & 0.75 & 0.75 \\
\hline 23 & Level of knowledge on tank management & 0.25 & 0.25 & 0.25 & 0.25 \\
\hline 24 & Level of training on tank management & 0.25 & 0.25 & 0.25 & 0.25 \\
\hline Total score (out of 24) & $\mathbf{1 4 . 2 5}$ & $\mathbf{1 3 . 7 5}$ & $\mathbf{1 4 . 2 5}$ & $\mathbf{1 4 . 5 0}$ \\
\hline
\end{tabular}


If two or more tanks have the same index then the tank with higher ratio of command area to waterspread area could be taken up first for rehabilitation. The order of prioritization for the selected tanks for rehabilitation was given in Table 4.

Table 4: Order of prioritizing the tanks for rehabilitation

\begin{tabular}{|l|l|l|l|}
\hline Sl. No. & Name of the tank & TRI & Rank \\
\hline 1 & Arungunam & 14.25 & 2 \\
\hline 2 & Mariputhur & 13.75 & 4 \\
\hline 3 & Devadur & 14.25 & 3 \\
\hline 4 & Kavadur & 14.50 & 1 \\
\hline
\end{tabular}

\section{CONCLUSIONS}

The conclusions derived from this study are:

i. The performance of the tanks in terms of their storage capacity was found to be good in the Arungunam and the Kavadur tanks whereas the Mariputhur and the Devadur tanks showed reduced performance due to siltation. Efforts must be taken to restore the original capacity of the tanks either by desilting the entire tank bed or by partial desilting with the help of the stakeholders.

ii. The depth of storage could be increased in the tanks as they show good hydrologic potential ensuring productive use of the surplus water. This helps the farmers to go for another season of cultivation with the tank water and also aids for other livelihood activities like increasing the groundwater recharge and drinking purposes.

iii. Proper training and awareness programs should be given to both the farmers and the Officials related to tank management thereby strengthening up the institutional aspects. The roles and functions of the tank users' associations must be highlighted.

iv. Proper communication between the farmers and the Officials must be ensured. A bottom up flexible level of management could be adopted for better performance of the system as a whole.

v. The Madurantakam high level channel could be desilted and maintained in such a way that the surplus water reaches all the 30 tanks in the cluster. If this channel functions properly, the livelihood of the farmers in the lower reaches improves and this may also prevent the tank from going unused due to water unavailability.

vi. Most of the people in the tank command area have agriculture as their major occupation. The study tanks are in the verge of exposure to the urban sprawl as the head tank Madurantakam is currently facing this issue. The policy makers must keep in mind the dependency of people on tanks and make appropriate frame work to protect the water resources from going unbeneficial due to the landuse changes in the command area, which may gradually lead to encroachment along the waterbodies and finally cause disappearance of the tanks.

\section{REFERENCES}

- Palanisami, K., \& Meinzen-Dick, R. (2001). Tank performance and multiple uses in Tamil Nadu, South India. Irrigation and drainage Systems, 15(2), 173-195.

- Nagarajan, R. (2013). Tank rehabilitation index for prioritization of lakes in semi arid regionsGeospatial approach. International Journal of Geomatics and Geosciences, 3(3), 525-537.

- Krishnaveni, M., Sankari, S., \& Rajeswari, A. (2011). Rehbailitation of Irrigation Tank Cascade System Using Remote Sensing GIS and GPS. International Journal of Engineeering Science and Technology, 3(2), 1624-1629.

- Abdul Hakeem, K., \& Raju, P. V. (2009). Use of high-resolution satellite data for the structural and agricultural inventory of tank irrigation systems. International Journal of Remote Sensing, 30(14), 3613-3623.

- $\quad$ Sakthivadivel, R., Fernando, N., Panabokke, C. R., \& Wijayaratna, C. M. (1996). Nature of small tank cascade systems and a framework for rehabilitation of tanks within them. IIMI Country Paper, Srilanka No.13.

- Jana, S. K., \& Lise, W. (2013). Participation in Tank Irrigation Management in Dry Zones in India, European Water Publications, 42, 35-50.

- Operating Instructions: Mobile River Discharge Measurement System OTT Qliner 2, www.ott.com, accessed on $14^{\text {th }}$ February 2018. 